\title{
Formação heterogênea da paisagem e experiências urbanas no bairro Floresta, Porto Alegre/RS
}

Heterogeneous landscape formation and urban experiences in the
Floresta neighborhood, Porto Alegre/state of Rio Grande do Sul

Luiz Henrique Apollo [I]

Vitoria Gonzatti de Souza [II]

\section{Resumo}

Este artigo apresenta as relações complexas entre processos sociais e espaços materiais no bairro Floresta, inseridos no histórico das transformações socioeconômicas ocorridas no 4 을 Distrito de Porto Alegre. Elas são materializadas por diferentes elementos, desde o processo de sua industrialização, esvaziamento e reapropriação. Assim, são construídos ambientes urbanos, conforme os usos organizados pelos atores sociais em territorialidades, pertencentes às três fronteiras urbanas que constroem esse espaço de contrastes. A metodologia aplicada foi qualitativa, de estudo explanatório, incluindo técnicas como caminhadas, o uso de registros fotográficos e de registros escritos. A partir dessa abordagem, foram identificadas tipificações dos espaços físicos e de seus usos, que expressam, de maneira segmentada, as vivências e os encontros em diferentes combinações de vínculos, memórias e conflitos.

Palavras-chave: paisagens heterogêneas; bairro Floresta; 4ㅇ Distrito de Porto Alegre; territorialidades; materialidades urbanas.

\begin{abstract}
The article presents the complex relationships between social processes and material spaces in the Floresta neighborhood, included in the history of socioeconomic changes that occurred in the $4^{\text {th }}$ District of Porto Alegre. They have been materialized by different elements, since the process of their industrialization, emptying and reappropriation. Thus, urban environments are built according to the uses organized by social actors in territorialities, belonging to the three urban borders that constitute this space of contrasts. The qualitative methodology of explanatory research was applied, including techniques such as walking and the use of photographic and written records. With this approach, typifications of physical spaces and their uses were identified, expressing, in a segmented way, experiences and encounters in different combinations of bonds, memories and conflicts.
\end{abstract}

Keywords: heterogeneous landscapes; Floresta neighborhood; $4^{\text {th }}$ District of Porto Alegre; territorialities; urban materialities. 


\section{Introdução}

O espaço é fruto tanto da espontaneidade, da sobreposição da ação social sobre o espaço, quanto de ações planejadas (Lefebvre, 2001). Assim, a forma da paisagem urbana é reflexo dos processos pelos quais o território passou em sua história, e sua constituição afeta os frequentadores dos locais, que, por sua vez, interagem de maneiras distintas conforme suas intenções. Nesse sentido, os atores sociais que constituem o espaço materializam no ambiente construído os processos distintos de pertencer (Corrêa, 2018).

A partir dessa relação, este artigo pretende desenvolver o encontro de sentidos de um lugar perante a trajetória da passagem de mudanças socioeconômicas que formou a sua paisagem heterogênea. 0 território em questão é o chamado 4음 Distrito de Porto Alegre, formado e contido em diferentes relações sociais no seu histórico particular da cidade. Essa região localiza-se logo ao norte do Centro Histórico da cidade, limitada à oeste pelo lago Guaíba e à leste por bairros que concentram populações de maiores rendas. É uma antiga área portuária que aportou diversos imigrantes desde o século XIX e onde se estabeleceram as primeiras indústrias na cidade.

A divisão municipal em distritos estava prevista na Constituição Política do Estado do Rio Grande do Sul de 1891. Apesar de não ser mais utilizada como divisão oficial da cidade, a denominação ainda está contida no Plano Diretor para designar a área em questão, o que compreende atualmente os bairros São Geraldo, Navegantes, Farrapos, Floresta, São João e Humaitá. Sucessivas etapas macroeconômicas levaram a formas distintas de desenvolvimento aos distintos bairros, sob as quais se constituíram panos de fundo para a construção de uma diversidade de paisagens urbanas. Tais paisagens foram sendo atreladas às funcionalidades de cada espaço, conforme a constituição dos diferentes atores sociais que foram ocupando e desocupando o local.

Os atores sociais são enquadrados, na perspectiva de Bourdieu (1983), como agentes que reproduzem uma estrutura na situação de conflito que emerge pelas relações de dominação estruturada na organização desse espaço urbano e incorporada em seu elemento de identidade, pertencente a um determinado grupo. Dessa forma, resultam territorialidades distintas, contrastadas em ambientes tais como vilas, moradias de classe média, áreas fabris, ruínas, áreas comerciais e edifícios contemporâneos com fachadas espelhadas. Por territorialidade, 0 artigo foca no conceito construído por Rogério Haesbaert em sua perspectiva relacional de um conjunto de relações complexas entre processos sociais e espaços materiais, em que

[...] além de incorporar uma dimensão mais estritamente política, [a territorialidade] diz respeito também às relações econômicas e culturais, pois está intimamente ligada ao modo como as pessoas utilizam a terra, como elas próprias se organizam no espaço e como elas dão significado ao lugar. (Haesbaert, 2004, p. 3)

O bairro Floresta, em específico, é o recorte de delimitação geográfica introduzido para selecionar esses processos de transformações socioeconômicas, relacionados com a industrialização e o declínio desse setor que fora aglomerado na área do 4 음 Distrito de Porto Alegre em suas diferentes formas de ocupar. Esse bairro é o estudo de caso da pesquisa em desenvolvimento do Grupo de Pesquisa em 
Sociologia Urbana e Internacionalização de Cidades (GPSUIC/UFRGS), circunstância na qual se insere o desenvolvimento deste trabalho.

Nesse contexto, o artigo pretende apontar as conexões causais entre as transformações históricas e a materialização da paisagem urbana do bairro Floresta efetuadas em suas distintas territorialidades. Para isso, serão analisadas a trajetória da passagem de mudanças socioeconômicas relacionada ao processo de urbanização do 4음 Distrito de Porto Alegre. Posteriormente serão apontadas as distintas territorialidades construídas nesse bairro, a partir de suas paisagens heterogêneas e fronteiras percebidas pelos atores sociais presentes.

Esses atores sociais atribuem significados ao espaço pelas suas diferentes maneiras de convivência e práticas de seu cotidiano. Conforme aponta De Certeau (1998), são essas vivências e suas táticas de uso no território que constroem múltiplas formas de conhecer e se reconhecer no espaço na atribuição de identidades de valor. Além do mais, parte-se da atribuição desses sujeitos como atuantes no espaço social e que se apropriam da cultura econômica do território numa relação de pertencimento, de vínculos sociais e de traços de sociabilidade. Por isso, suas referências estão relacionadas aos seus interesses de permanência social no local, e suas ações e narrativas salientam a reflexividade dialógica e heterogênea de construção das diferentes paisagens no ambiente.

Foram realizadas caminhadas no bairro Floresta durante o ano de 2019 com quatro dos atores sociais presentes, além de uma caminhada inicial com caráter de reconhecimento e exploração primária da região. Os quatro atores sociais envolvidos nessa fase inicial da pesquisa são interlocutores do espaço em distintas representações em suas práticas no bairro, quais sejam: dois representantes de movimentos sociais com sede no Floresta, um dos mediadores dos empreendedores da economia criativa na região e um artista urbano que integrou equipe de grafiteiros em evento anterior realizado no bairro.

Nesse formato de percorrer o espaço, seguiu-se um percurso definido pelos próprios interlocutores que narraram e apontaram suas perspectivas. Adotou-se essa abordagem a partir de caminhadas para captar, nas ações dos interlocutores, as suas experiências, as suas práticas cotidianas e as interpretações de suas realidades sociais, aliando a análises de referências históricas sobre o desenvolvimento da região.

As caminhadas foram registradas em fotografias e em relatos escritos pelos pesquisadores. Dessa forma, foi possível captar o olhar desses atores sobre as paisagens urbanas, além de identificar diferentes traços de territorialidades dos atores sociais. 0 artigo construiu uma descrição analítica mapeada pelos significados que estabelecem o lugar, relacionado ao processo social com a história que remonta ao ambiente do 40 Distrito, em especial do bairro Floresta, perante as diferentes estruturas vigentes e interessadas no espaço, que expressam a dinâmica da multiplicidade de poder e de resistências.

Esse espaço, moldado pelos processos sociais, constitui-se por paisagens urbanas heterogêneas que evidenciam os conflitos e as passagens de mudanças estruturais, em que os atores estabeleceram diferentes relações. A interpretação dos sujeitos para explicação e aparência do ambiente é projetada e influenciada pelas suas vivências e saberes em cenários que demonstram as múltiplas e conflitantes 
narrativas urbanas existentes sobre o 4 음 Distrito: o tradicional versus o moderno; o popular versus o cool; o industrial versus as ruínas versus o comercial; os muros versus as conexões.

Para compreender esse processo, parte-se de um parâmetro histórico-dialético das cidades, materializado nos elementos e processos que as compõem, os quais geram a identificação de um lugar, conforme o tempo e, sobretudo, contextualizando seus vestígios, demarcando quem os produziu e com que objetivo, evitando o senso comum da neutralidade. Essa interação entre os atores sociais e a cidade, de poder acessar, usufruir e também poder conduzir a produção do espaço urbano, é parte do exercício do direito à cidade (Lefebvre, 2001; Harvey, 2014). Por isso, o espaço urbano não deve ser tratado como imutável, mas considerado como uma constante transformação social, e nós, enquanto sociedade, escrevemos a história desse espaço (Santos, 1982).

Tal "escrita" também permite uma "leitura" da paisagem urbana, essa composição de elementos relacionados - edifícios, anúncios, tráfego, árvores, etc. -, que cria o ambiente captado pela visão humana, conforme a localização, perspectiva e conteúdo (Cullen, 2015). Assim, depreende-se, aqui, que a leitura e a análise da paisagem devem estar vinculadas às vivências da sociedade no espaço. Portanto, a trajetória de uma paisagem contém não apenas chaves para a compreensão de questões que se discutem no presente, mas também se apresenta como um meio de identificar que paisagem está sendo materializada e percebida hoje e, sobretudo, como tais processos estão ocorrendo.

É a partir dessa perspectiva que este artigo se dividirá em três partes. De início, apontaremos a narrativa histórica construída de desenvolvimento do 4음 Distrito, atrelada ao processo de industrialização, enaltecida pela imigração alemã de capital comercial que constrói as primeiras fábricas. As relações sociais do novo operariado urbano no final do século XIX e início do XX trouxeram uma determinada paisagem de função de distrito industrial que modificou o seu passado rural, consolidado até meados da década de 1950.

Posteriormente, o artigo pretende apresentar o processo de desintegração desse modus operandi da região, com a saída das fábricas e a falta de investimentos no local, que geraram mudanças no cenário urbano, sobretudo pelos desusos e refuncionalização dos espaços em novas configurações de atores sociais que se estabelecem ou permanecem na região. Além disso, essa descrição analítica continua demonstrando a transformação contemporânea pela qual o bairro está passando, através de uma refuncionalização econômica, traçada por diferentes tratamentos e interesses dos distintos grupos sociais que compõem a desindustrialização.

Por fim, trataremos sobre as diferentes fronteiras urbanas que acabaram sendo constituídas ao longo do histórico do bairro Floresta, resultado das grandes vias que foram abertas para escoar os produtos na logística das fábricas e portos existentes. São elas: avenida Cristóvão Colombo, avenida Farrapos e rua Voluntários da Pátria. Essas fronteiras e seu nítido contraste são examinados em subtópicos que demonstram as transformações das paisagens urbanas em vínculos e usos de diferentes atores sociais em suas experiências urbanas cotidianas. Por fim, a conclusão arremata as principais análises exploratórias das caminhadas e lança luz para futuras investigações. 


\section{Ocupação e industrialização do 4 을 Distrito}

A região onde está situado o 4을 Distrito de Porto Alegre foi uma concessão de terra solicitada pelo então governador da Província em 1812, Dom Diogo de Souza, a fim de desenvolver uma área agrícola, com demarcação de lotes e atração da população à região afastada do centro da cidade. Dona Margarida Teixeira de Paiva era proprietária de uma importante área que abrangia terras fronteiras ao Caminho Novo - atualmente rua Voluntários da Pátria, e foi, nesse loteamento, situado no atual bairro $\mathrm{Na}$ vegantes, que se iniciou uma paisagem de chácaras e quintas, além da construção da estrada de ferro ligando Porto Alegre a Novo Hamburgo, que passou a operar a partir de 1874.

Devido à estrada de ferro e ao estabelecimento do porto no Guaíba, o processo de imigração tornou-se ainda mais presente, principalmente pelos colonos alemães que vinham se estabelecendo desde 1824 na província, em acordo da recém-unificada Alemanha com o Império Brasileiro, com o fim de inicialmente ocupar o interior, precaver a economia e substituir a mão de obra escravizada. A economia agrícola colonial dos primeiros imigrantes começa a ter maior relevância, gerando o aumento do fluxo de matérias-primas e uma acumulação de capital relacionada ao comércio, à formação do mercado regional e à diversificação produtiva (Costa, 1989). É por essa acumulação de capital de algumas famílias que ocorrem a expansão do comércio e a construção das primeiras pequenas indústrias de bens de consumo não duráveis no final do século XIX, iniciando paulatinamente o desenvolvimento da industrialização do estado do Rio Grande do Sul.
A atuação do imigrante no desenvolvimento sul-rio-grandense, segundo Pesavento (1985), relaciona-se à participação do "burguês imigrante", ou seja, "aquele que trouxe consigo, da sua terra de origem, capital e experiência profissional na gestão de alguma empresa" (ibid., p. 32). São os chamados "artesãos de transformação", que visavam expandir os ofícios de marcenarias, sapatarias e cervejarias para uma escala comercial (Roche, 1969).

Diversos exemplos de fábricas de imigrantes alemães construídas remontam a essa época em Porto Alegre, tais como a cervejaria Bopp, inaugurada em 1881, pertencente a Frederico Cristofel; a cervejaria Ritter, inaugurada em 1894, por Henrique Ritter; a fábrica de chocolates Neugebauer, inaugurada por Ernesto Neugebauer, em 1891. A seguir ilustra-se uma imagem da localização dessas principais fábricas, inauguradas, sobretudo, nesse período até 1950 (Figura 1).

A aglomeração das fábricas aumentou o fluxo de comércio (Spalding, 1967) principalmente na rua Voluntários da Pátria, e o cenário das chácaras passa a ser substituído pelos estabelecimentos comerciais e industriais desses imigrantes, o que elevou a confluência econômica e cultural da região. A construção identitária que se cria dos imigrantes alemães é muito presente na narrativa histórica da região, relacionada à moral trabalhadora e ao desenvolvimento industrial daquele espaço na cidade. São sujeitos considerados indivíduos pacíficos, honestos, com capacidade de progredir pelo trabalho árduo, reforçando a verbalização do espaço de que ali morava uma "boa classe média" e um ethos produtivista bemquisto (Constantino, 1998), em contraponto à figura mítica do trabalhador brasileiro visto como "malandro" e "vagabundo". 
Figura 1 - Principais fábricas que estiveram presentes no 4 을 Distrito entre 1870 e 1950

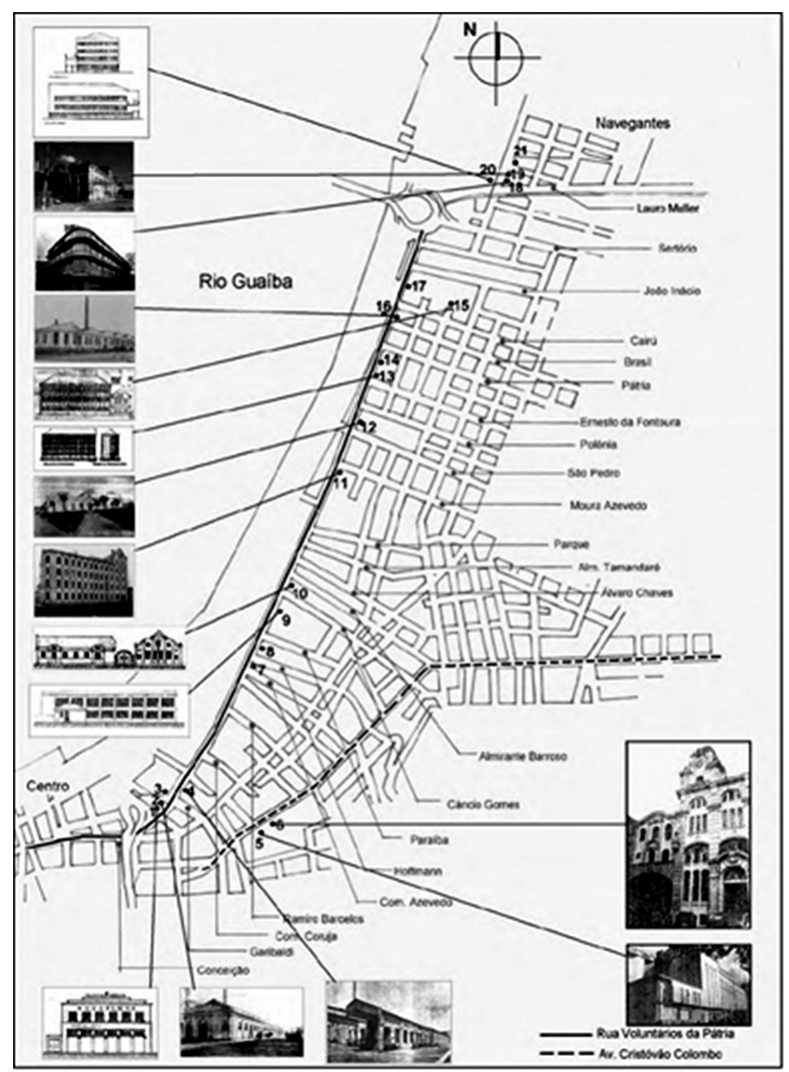

Fonte: redesenho a partir da planta de Porto Alegre na escala 1: 15000. Mapoteca da Smov, (Miranda, 2003).

Segundo relatório da subintendência de Porto Alegre, de 1918, para esse Distrito, o número de habitantes recenseados era de 19.379 pessoas, das quais 3.090 eeram classificadas como operários, enquanto 1.214 seriam "jornaleiros", provavelmente se referindo aos trabalhadores temporários nas indústrias. Além do mais, havia as 5.827 "domésticas", que incluíam as empregadas domésticas e as donas de casa, e os 6.728 "sem profissão" (fora da idade produtiva). Tem-se, nesse ano, $45 \%$ de "operários" e 17,17\% de "jornaleiros" entre as ocupações declaradas (Pesavento, 1988, apud Fortes, 2001). Dessa maneira, a concentração no território aliou-se à identidade de uma cultura socioespacial operária a partir do início do século $X X$, de famílias que viviam em torno das fábricas que entrecruzaram paulatinamente a industrialização com a expansão urbana.

O bairro Floresta, por exemplo, representava essa camada social intermediária, alimentada pela carga afetiva dos imigrantes 
alemães com suas propriedades residenciais e de pequenos comércios. Uma rua como referência é a antiga rua do Floresta - atual avenida Cristóvão Colombo - devido à incidência de diversos sobrados, cerca de $5 \%$ dos imóveis, que eram propriedades de poucas famílias de imigrantes - em sua maioria alemães, tais como Wendesh, Becker, Bopp, Brockmann, Raupp, Mayer e Miraglia.

A importância desse grupo ainda se intensificou por meio das estreitas ligações econômicas que fortaleceram as ligações culturais e preservaram línguas e costumes desses emigrados (Cunha, 2006) de diversas regiões, inclusive Leste Europeu. Ali se estabelece uma semântica do espaço em relações sociais que historicamente se desenvolve como área de progresso e uma carga afetiva dos recém-chegados pela sua proximidade cultural, mantendo a indústria um papel na reprodução da própria estrutura familiar e efeitos nas relações comunitárias. São exemplos da constituição de sociabilidade diferentes associações tanto de lazer, esporte ou religiosas que foram construídas na zona: a Sociedade Polonesa, a Sogipa, a Sociedade Gondoleiros; as Igrejas de Nossa Senhora dos Montes Claros, ortodoxas russa e ucraniana; de vários templos católicos e protestantes (Constantino, 1998).

Além dessa imigração europeia, a população negra também detinha sua representação, muitas vezes invisibilizada na memória da região, construída pela Sociedade Beneficente Floresta Aurora, fundada em 31 de dezembro de 1872 , sediada nas proximidades da rua Aurora, hoje denominada rua Dr. Barros Cassal. Ela tinha como objetivo a luta e assistência para alforrias e visava reunir músicos negros em atividades lúdicas, momentos políticos e religiosos em ações de caráter mutualista.
A mudança processual para a economia industrial estabeleceu novas relações de trabalho, e a presença dominante da indústria também consolidou o movimento social do operariado. Uma onda de movimentos grevistas assinalou-se, no Rio Grande do Sul, estendendo-se pelos anos de 1918 a 1920, devido ao descontentamento de desemprego, à escassez de produtos alimentícios básicos e ao aumento de preços, apesar do progresso industrial da região. Havia diferentes frentes, algumas de maiores audácias, como os grupos anarquistas que foram fortes combatentes (Petersen, 2001) e que pressionaram o Partido Republicano Rio-grandense (PRR) para a obtenção de direitos trabalhistas ao mesmo tempo que levou a permanência do PRR no poder em Porto Alegre.

Foi a partir da gestão do prefeito Otávio Rocha, em 1924, com o seu vice, Alberto Bins, que a cidade passou a intervir com investimentos de maneira mais presente, fornecendo o abastecimento de água tratada e elevando o número de moradias na área. Assim, na cidade, as chaminés foram proliferando-se e tornando-se elementos presentes na região devido à industrialização, em fábricas, sobretudo dos ramos de alimentação, metalurgia e têxtil (Titton, 2012). As indústrias que se estabeleceram e se desenvolveram nessas décadas foram diversas, dentre elas estão a Fundição Berta, de Alberto Bins; as fábricas de cerveja Cristoffel e Ritter; a Cia Fiação e Tecidos Portoalegrense; a Fiateci Cia Fabril Portoalegrense; a fábrica de pregos Pontas de Paris; a fábrica de móveis Vergados João \& Walter Gerdau; a fábrica de fogões Wallig; os moinhos: Riograndense, Moinho Chaves; a fábrica Renner; a fábrica de chocolates Neugebauer; além de diversos armazéns instalados, devido ao porto (Silva, 2019). 
Posteriormente, o governo do intendente Loureiro da Silva (1937-1945), visando o aumento na economia industrial da cidade, ampliou os investimentos para a área: a construção de diques para evitar inundações e a abertura da avenida Farrapos em 1940, com o seu alargamento para 30 metros, cortando os bairros Floresta, São Geraldo e Navegantes, com um traçado calculado com base no menor custo das indenizações para as desapropriações necessárias às obras de abertura da avenida (Figueiró, 2007). Sua construção permitiu a ligação do centro de Porto Alegre a sua zona industrial e à saída da cidade através de tráfego rápido (ibid.) sendo, portanto, um importante marco do seu estágio de industrialização, já em um momento de crescimento da população urbana na cidade.

Desde essa época, a região passa a ter uma vida independente em relação à cidade com um cenário composto por inúmeras casas, comércio diversificado, indústrias, teatros, cinemas, salões de baile e agradáveis espaços verdes para estimular interação entre os moradores (Mattar, 2010). Além do mais, a inauguração da avenida Farrapos coincidiu com o período de ascensão do estilo arquitetônico Art Déco no Rio Grande do Sul, de forma que essa grande avenida, tomada à época como representação do progresso e da modernidade, recebeu uma sequência homogênea de edificações nesse novo estilo, muitas preservadas até a atualidade (Figueiró, 2007).

A promoção de maior industrialização no País elevou o êxodo rural a partir da década de 1940 e 1950, no estado do Rio Grande do Sul, e uma proliferação da vinda de mão de obra operária à cidade, com operários ocupando moradias próximas ao local de trabalho em conjuntos construídos e explorados de aluguel pelos donos das fábricas (Titton, 2012), bem como através de linhas de crédito de financiamento do Estado ou pelo mercado imobiliário, devido ao alto valor que já se destinava ao espaço. São residências com a tipologia de casas em fita, que foram sendo construídas para abrigar os operários, como é preservado até hoje em partes dos bairros.

Além desse tipo, o número de loteamentos irregulares e habitações precárias próximas às fábricas também aumentou, estabelecendo uma grande miscigenação de culturas, experiências e adaptações de uma identidade própria de "bairro-cidade" (Mattar, 2010), já que o chamado 4ํㅡㄹ Distrito dispunha, então, de todos os principais usos do solo urbano contidos em sua dinâmica interna.

A partir do primeiro Plano Diretor de Porto Alegre, a denominação distritos entra em desuso e a cidade acaba sendo setorizada por bairros, apesar da permanência da denominação do 4음 Distrito como referência na atualidade, o que ocorre apenas com esse antigo distrito e não com os demais. O Plano Diretor de 1959 ainda manteve boa parte da área que hoje engloba o Floresta e, mais amplamente, o 4 음 Distrito, demarcada como zona de uso essencialmente industrial (Porto Alegre, 1959), desconsiderando as dinâmicas urbanas heterogêneas daqueles bairros.

Dessa forma, o processo de industrialização na região apresentou uma forte imposição à paisagem urbana para modernização, que se vinculou às suas características geográficas preexistentes, com a imigração de diferentes grupos sociais e o dinamismo de seus atores, que desenvolveram uma ideia de urbanização da cidade. Esses locais, tais como grandes galpões, fábricas, moradias operárias e de propriedade da antiga classe média, além de 
antigos clubes, construíram seus objetos de memória para promover suas identidades socioculturais. Os novos usos que se observam são vinculados às atividades integrantes de distintos cursos de ação no território, como, por exemplo, as atividades de serviços, reciclagem e atividades do setor criativo - itens a ser explorados com mais detalhes em seções seguintes, diante do curso do processo de desindustrialização dessa área.

\section{Processo de desindustrialização}

Na década de 1970, inicia-se o processo de suburbanização e metropolização da atividade industrial, impulsionado pelo programa do estado do Rio Grande do Sul para a desconcentração industrial da capital e a implantação de loteamentos industriais na Região Metropolitana em diferentes distritos industriais para cada cidade. O Plano Diretor de 1979, ainda muito na perspectiva do modernismo, manteve o uso de zoneamento para dividir a cidade em unidades territoriais, demarcando boa parte do que antes era apenas 'industrial' agora como "comercial e serviços", e também área "mista", contudo, ainda mantendo uma unidade territorial marcada como "industrial" mais ao norte da área do 40 Distrito (Porto Alegre, 1979).

A expansão da malha viária com o remodelamento dos trens urbanos (Trensurb) e a rede interna da cidade que se ampliou e valorizou o preço dos imóveis na capital fizeram com que as indústrias e a classe trabalhadora se transferissem para áreas mais afastadas, de valores de solo mais baixos do que os encontrados no 4음 Distrito em Porto Alegre. Segundo levantamento de Fernandes (2014), a permanência de indústrias com mais de 100 empregados em Porto Alegre teve uma queda de um total de 60 empresas, em 1971, para 32, entre 1991 e 1992, e para somente 5 quando finalizada sua análise, em 2008. Foi um processo que gerou o esvaziamento rápido da área, semelhante as tendências que ocorriam em outros cemitérios industriais de diversas cidades do mundo, como em Detroit, nos Estados Unidos. Isso fez com que a área do 4 음istrito, destinada com exclusividade à atividade industrial, experimentasse desvalorização, descaso, percepção de perigo pelo desuso e falta de investimento público e privado.

Esses deslocamentos das fábricas ocasionaram desemprego na área, fragmentação social, vazios urbanos, falta de novos investimentos e rompimento dessa divisão social do trabalho relacionada a essa estrutura fordista de acumulação de capital produtivo. Contudo, as formas da paisagem urbana construída para habitação, logística e indústria ainda se mantiveram, caracterizando a região que rememora as combinações sociais que constituíram aquele território. Foram setores administrativos, depósitos e armazenagem que permaneceram na área, apesar dos novos arranjos desconfigurarem as relações socioeconômicas atreladas à indústria.

Tanto a persistência na tentativa de destinar a área às atividades industriais não foi exitosa quanto foi um fator que impediu o completo rompimento do território com essa característica, de forma que toda a herança de grandes lotes (por vezes quarteirões inteiros ou quase isso), as "carcaças" industriais, os galpões, as chaminés e as moradias operárias mantêm-se, em muitos casos, aparentemente intactas até a atualidade. Assim, uma área que tinha uma função industrial dependente 
do sistema fordista rapidamente foi desconstituída, reorganizando o espaço devido aos interesses da sociedade dominante que previu maiores vantagens em abandonar a cidade indo para outra região. Os símbolos culturais criados de vilas operárias, comércio e vias urbanas construídas para o escoamento dos produtos permaneceram, mas os valores econômicos tornaram-se incompatíveis, devido ao desinteresse do capital em investir na área. Por isso, desde a consolidação desse panorama, a região do 4 을 Distrito subitamente ficou com aparência de abandono.

Devido aos esforços de constituição econômica do setor de serviços, algumas áreas, pela sua proximidade ao centro, transformaram-se rapidamente. 0 bairro Floresta, em especial, estabeleceu-se em um local com bastante variedade de atividades, população e estéticas urbanas. Por setores econômicos, a avenida Cristóvão Colombo passou a acumular diversas atividades comerciais, tais como hotéis, supermercados, lojas, shopping center. O cenário urbano da área residencial das vilas operárias e antigos sobrados permaneceu. Além do mais, ainda se mantiveram algumas realizações de sociabilidade operária como as festividades para as crianças no mês de outubro que, desde 1975, são realizadas na mesma avenida, organizadas posteriormente pela Associação Amigos da Cristóvão Colombo, atrelada ao setor de comércio da área.

Em contrapartida, a saída das fábricas em vasto número tornou o outro lado do bairro, sobretudo entre a rua Voluntários da Pátria e Farrapos, onde as fábricas estavam localizadas, em um espaço de grandes galpões abandonados entre muros e, assim, de vazios urbanos. Esse local tornou-se uma área subvalorizada e, por isso, permaneceram ocupações de alguns moradores com menor poder aquisitivo. Além do mais, ainda se concentram lojas de mecânicas, algumas fábricas, atividades de prostituição, hotéis e motéis antigos, ocupações e centros culturais populares, tais como a escola de samba Bambas da Orgia.

Por fim, na rua Voluntários da Pátria é onde se encontram ainda algumas fábricas, galpões e áreas de reciclagem, bem como na Vila Santa Terezinha - conhecida por "Vila dos papeleiros", estigma atribuído devido à principal atividade econômica dos moradores que habitam o loteamento. A Figura 2 demonstra a diversidade e a quantidade de serviços de consumo (traço em laranja), convívio (escolas, abrigos, espaços de cultura, marcação em laranja, azul e verde), locais socioassistenciais (sobretudo representados pelos Cras - guarda-chuvas no mapa), assim como espaços sociais memoráveis e de habitação social (pensões, edifícios desocupados e de interesse social no bairro - pontos em azul, amarelo, verde, laranja e vermelho no mapa).

Após o período de 1980, de mudança e substituição de atividades e população na área, novas orientações para projetos urbanos foram propostas pelo poder público local, que desde a década de 1990, já enxerga o território como um espaço destinado a ser requalificado de alguma maneira, levando a sua demarcação no atual Plano Diretor (Porto Alegre, 2010) como área para Operação Urbana Consorciada. Assim, passado seu processo de desindustrialização, os planos atualmente buscam imputar à área do 4 음 Distrito um novo rumo, vinculando a ele ideias como resiliência, tecnologia, cultura, inovação e empreendedorismo.

Projetos com diferentes articulações inserem-se em processos de disputa e de desenvolvimento como retórica, que acabaram 
Figura 2 - Serviços no bairro Floresta - 2016

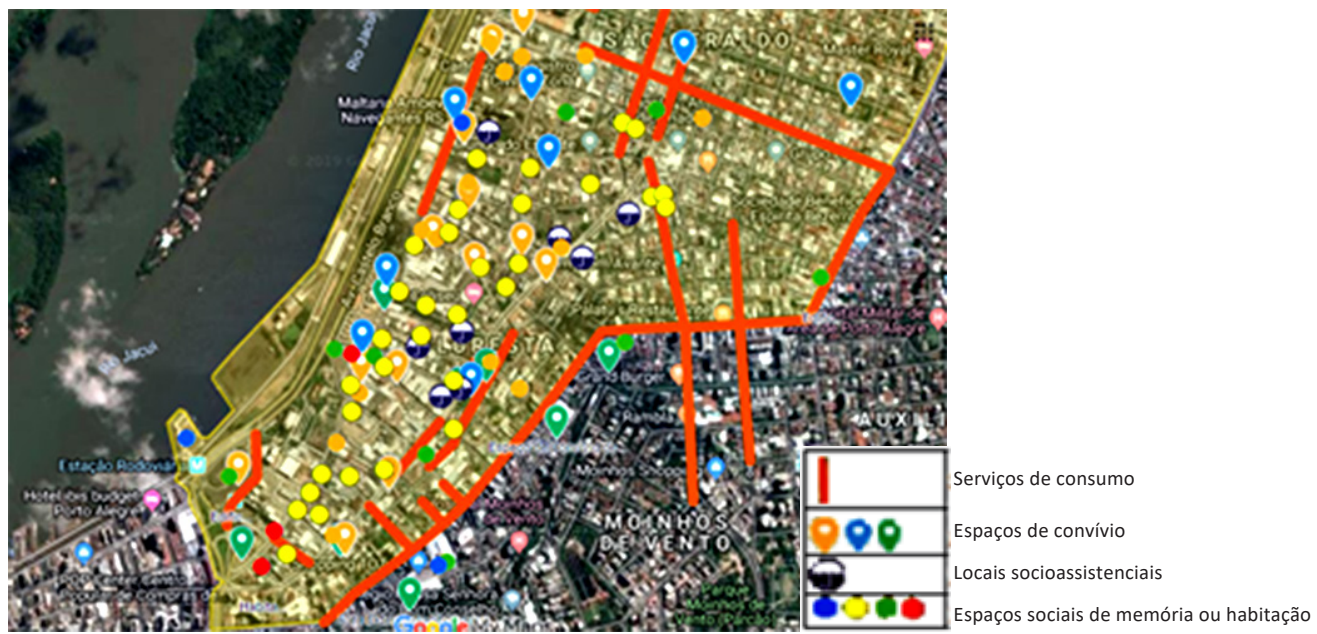

Fonte: 3으 Ciclo Social Workshop 4o Distrito - mapa colaborativo, 2016.

gerando debates a partir de 1995, como o Porto Alegre Tecnópole e o Projeto Integrado de Entrada da Cidade (Piec), já em 2000. Ainda, ali se destinaram algumas obras para abrigar a Copa do Mundo de Futebol em 2014, devido à preocupação do escoamento veicular das avenidas e do embelezamento para o turismo. Mais recentemente, o projeto de revitalização urbanística no 4을 Distrito concentrou-se nos seguintes: Porto do Futuro, Masterplan e Porto Alegre Resiliente em 2016, com engajamento político ampliado para o poder público municipal, pequenos comerciantes e maiores investimentos privados.

Essas narrativas provocam mudanças, aos poucos, na atração de profissionais criativos, inovadores e empreendedores com alta formação profissional e de maneira retroalimentadora, que valorizam e "requalificam" a região, modificando a imagem de uma área degradada. Em contrapartida, ainda há a negligência das diferentes áreas pelas demandas sociais dos moradores atuais que vivem em maior vulnerabilidade social.

\section{Diferentes territorialidades construídas no Floresta}

Os processos históricos desde o início da ocupação da área até o momento presente subscrevem sobre o mesmo território uma heterogeneidade, a qual expõe a existência de uma relação conflitual. Ao mesmo tempo que a paisagem em transformação permite uma convivência de tipos arquitetônicos contrastantes e de diversificadas atividades, que 
é positiva - elementos de diversidade e da sua consequente vitalidade urbana (Jacobs, 2011) - ela também evidencia um processo de contornos e objetivos ainda nebulosos, mas já com sinais de exclusão das populações mais vulneráveis ali presentes. Essas diferentes formas de utilizar o território se dão pelos remodelamentos das paisagens urbanas conforme as funções socioeconômicas que foram modificadas.

Tomando como base as primeiras saídas de campo realizadas no bairro Floresta, a partir do olhar de diferentes atores sociais presentes na região (representantes da economia criativa, de ocupações e de grafite), três fronteiras foram diagnosticadas, sendo duas localizadas na porção interna e uma na borda do bairro. São as três avenidas principais que denotam essas divisões. A avenida Farrapos e a rua Voluntários da Pátria demarcam áreas de características distintas por dentro do bairro Floresta; ao passo que a avenida Cristóvão Colombo demarca a fronteira com o bairro Moinhos de Vento, este último tradicionalmente considerado um bairro nobre de Porto Alegre, com um dos $\mathrm{m}^{2}$ mais caros da cidade. A Figura 3 ilustra a delimitação do bairro Floresta e auxilia na visualização dessa configuração.

Figura 3 - Delimitação do Bairro Floresta - 2016

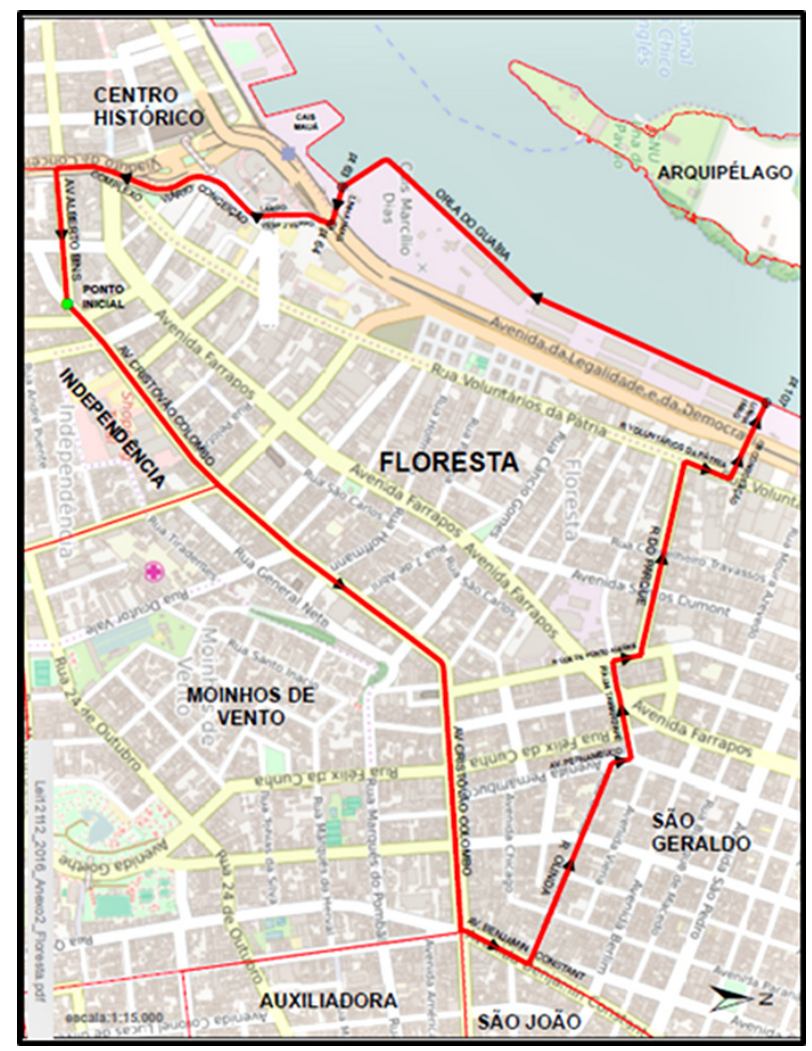

Fonte: PMPA, Smurb, Lei de Bairros 12.112, 2016. 
Essas divisões fortaleceram diversas territorialidades pelos atores inseridos de distintas funções destinadas a cada recorte do bairro. São aglomeração de diferentes grupos sociais em cada uma das áreas, os quais constroem experiências particulares nos seus convívios internos, embora, desconexas umas às outras. São relações estabelecidas entre espaço geográfico, intencionalidade e imaginação que são definidos pelos elementos constituintes (Araujo e Haesbaert, 2007) e que corroboram práticas do cotidiano definindo o uso e o processo identitário (De Certeau, 1998).

Assim, essas territorialidades foram sendo produzidas a partir da heterogeneidade da estética urbana, no usufruto dos espaços para alocação de serviços, de economia criativa, de galpões de catadores, de moradia social, de atividade cultural, de comércio popular, dentre outros usos, que se misturam em seus tipos arquitetônicos de patrimônios preservados, de ruínas e de edifícios contemporâneos. A partir da referida heterogeneidade no território, o artigo analisará cada uma dessas fronteiras e paisagens, a seguir.

\section{Fronteira Cristóvão Colombo}

A avenida Cristóvão Colombo é a base geográfica do morro que leva ao bairro Moinhos de Vento e estabelece o limite do bairro Floresta. Com prédios de poucos pavimentos, com antigos sobrados, grandes patrimônios preservados, ruínas transformadas em garagens e com prédios contemporâneos de fachadas espeIhadas, ela é uma avenida onde se concentra um grande número de serviços comerciais. Sua infraestrutura enjambrada liga o centro ao norte da capital com linhas de ônibus que se entrecruzam aos carros, sobre um asfalto precário, com rachaduras que mostram algumas ferragens das antigas linhas de bonde que passavam por esse local.

Essa é a avenida que constitui a fronteira socioeconômica de uma classe média estagnada, ligada à produção industrial e à comercial-financeirizada que manteve uma ascensão e alta concentração de capital. 0 contraste é visível nos investimentos, nos serviços e na urbanização. Segundo o Atlas do Desenvolvimento no Brasil, com dados de 2010 (PNUD, 2014), a região entre a rua Marquês do Pombal e a avenida Cristóvão Colombo, que agora está anexada ao bairro Moinhos de Vento, ${ }^{1}$ possui uma renda per capita de $\mathrm{R} \$ 3.417,25 ; 78,16 \%$ de pessoas entre 18 e 20 anos com escolaridade correspondente ao ensino médio; e Índice de Desenvolvimento Humano (IDH) de 0,927. Por sua vez, a área que compreende o interior do bairro Floresta (entre a avenida Cristóvão Colombo e a rua Voluntários da Pátria) possui uma renda per capita de $\mathrm{R} \$ 2.512,15$; escolaridade de 69,54\%; e IDH de 0,878. Claramente há uma distinção, em que o muro invisível da avenida divide o que antes unia a cultura germânica presente na construção dessa parte da cidade.

Apesar do nome antigo de rua do Floresta, ela constitui-se, atualmente, de pouca arborização e de bastante movimento de pessoas e automóveis, além de grande heterogeneidade em tipos arquitetônicos, com edificações construídas em diferentes contextos históricos e funcionalidades. Os antigos operários das fábricas foram dando lugar aos comerciantes, consumidores e trabalhadores do terceiro setor, em locais que abrigam escritórios, clínicas médicas, farmácias, supermercados, shopping 
center, academias, mecânicas, serviços de alimentação, escolas de arte, hotéis, livrarias. $\mathrm{Na}$ avenida Cristóvão Colombo, pessoas e carros circulam no fluxo norte-centro da cidade em uma via marcada pela presença de emaranhados fios elétricos.

O barulho constante da agitação dessas atividades que marcam a avenida Cristóvão Colombo é apaziguado quando se adentra o interior do bairro Floresta. As calçadas tornam-se mais largas, as árvores estão por diversos locais, as ruas de paralelepípedo diminuem a velocidade com que os automóveis passam, silenciando muitos ruídos, sobretudo em contraste com essa fronteira do bairro. Nesse interior, são encontradas diferentes formas de ocupação do espaço, e a sua narrativa histórica teuto-brasileira ainda é permanente. As casas em fita e sobrados preservados e consolidados em pequenos lotes são os que remontam essa história de antiga sociabilidade imigrante e operária da região.

São poucas as quadras que se distanciam da avenida Cristóvão Colombo até a avenida Farrapos, que cortam essa fronteira aqui apontada, mas que têm o seu prolongamento de centro para o norte, até o limite com o bairro São Geraldo, na rua Olinda. A arborizada praça Florida - oficialmente praça Bartolomeu Gusmão - é o coração do bairro, nela havia convívio de lazer, esportes, festas e confraternização da comunidade que existia no início do século XX (Franco, 1992), pelas diferentes presenças que construiam as territorialidades dessa parte da região. Ali também é se encontra uma escola infantil, além de feiras de vegetais e brechós organizados pelo Grupo de Apoio à Revitalização do Bairro Floresta, o Refloresta.
Aproveitando o local de infraestrutura, localização e aluguel vantajoso, é nesse espaço em que se concentram investimentos das camadas médias urbanas dos profissionais da economia criativa, que tentam revalorizar a região pelo desenvolvimento de um turismo criativo. Essa estratégia consiste em dar uma forma de visibilidade ao território com enaltecimento de uma narrativa histórica estruturada em seus patrimônios históricos reunidos para construir um valor de troca de promoção de revitalização por marketing urbano (Arantes, Maricato e Vainer, 2000). São aglomerações de escritórios de coworking, brechós, pubs, cafés, espaços multiculturais, museus, ateliês, estúdios de gravação, espaços de bicicletas, agências de publicidade, que criam uma rede ligada a valores identitários de uma determinada qualidade cultural de um público externo, glamourizada, moderna e cool (Zukin, 1989).

Essa tentativa de embelezamento contrasta com as territorialidades que se mantêm na região, tais como as trabalhadoras do sexo da rua São Carlos, que atraem uma dinâmica noturna histórica de prostituição atrelada ao porto entre as sombras das árvores do bairro. Além do mais, também estão presentes outros atores, tais como carroceiros transeuntes, moradores de rua, residentes antigos, ocupações e pequenos serviços comerciais, cada qual reivindicando seu espaço, conforme as consequências e relações econômicas que foram adequando a região. São constrastes e conflitualidades do território, cuja diversidade de atividades abarca a paisagem da fronteira (Figura 4).

Dessa maneira, o bairro estrutura-se por contrastes de comércios populares, sobreviventes da recessão do bairro (serviços de 
Figura 4 - Elementos da paisagem que compõem a fronteira Cristóvão Colombo e sua área interna no bairro Floresta
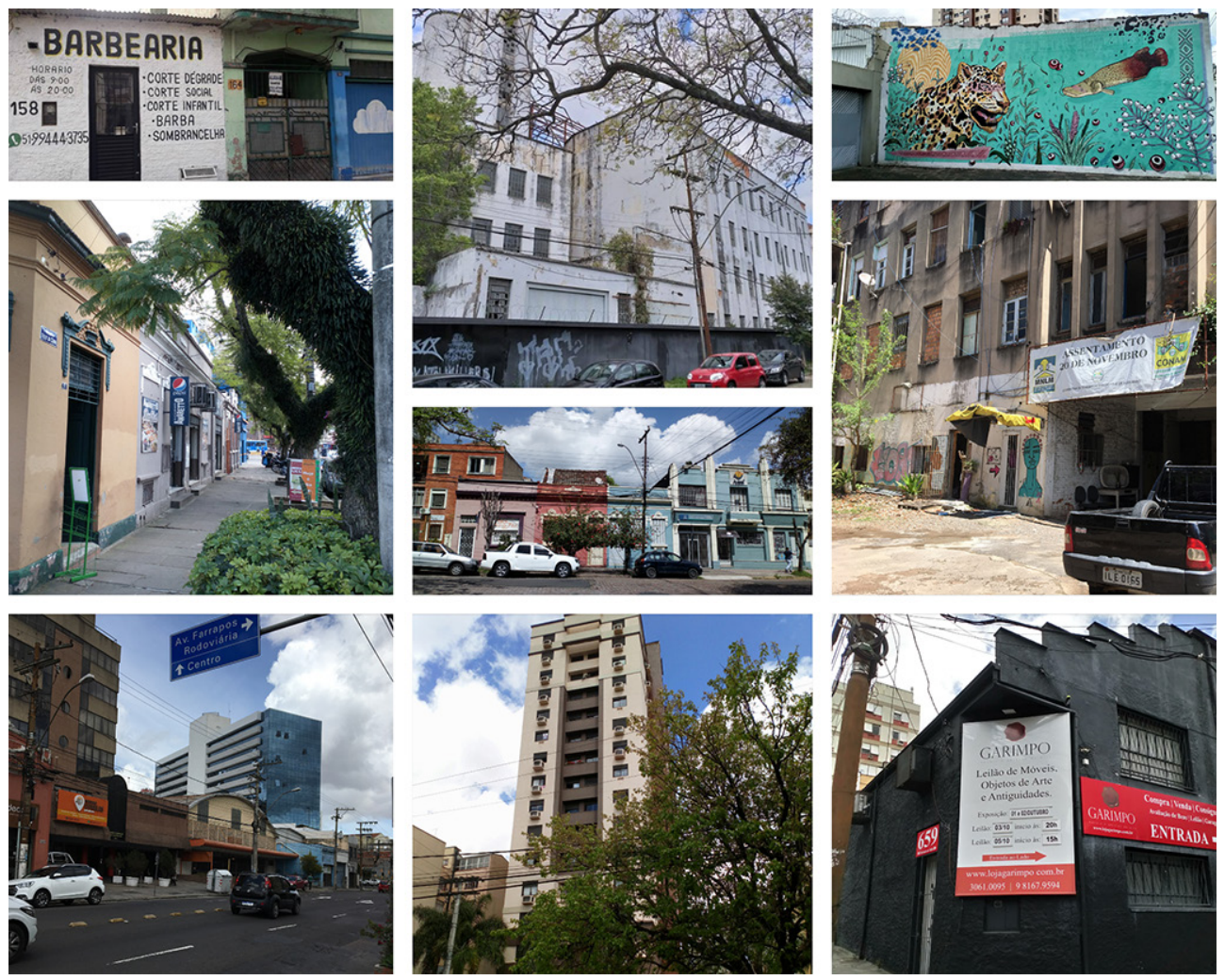

Fonte: trabalho de campo do GPSUIC, em 2019.

costureira, mecânica e pequenos bares) com essas novas funcionalidades criativas que são embelezadas pelos grafites encontrados na região, com muros pintados, em diversos casos, por financiamento cultural. Esse cenário urbano também conta com residências antigas típicas de um bairro que preserva suas raízes de narrativas tradicionais, além de prédios e residências mais contemporâneas que atraem novos moradores.

Contudo, as placas de "vende-se" e "aluga-se" são frequentes, e a desocupação do espaço demonstra a desvalorização ainda corrente do poder público e privado, sobretudo apontada pelas ruínas das antigas fábricas que evidenciam os vazios urbanos naquele território. Em alguns, existem ocupações, como o Assentamento 20 de Novembro, organizado pelo Movimento Nacional de Luta por Mora$\mathrm{dia}$, em outros, permanece $\mathrm{o}$ interesse de especuladores imobiliários. Ainda assim, esse cenário de desuso, principalmente dos grandes galpões, é mais evidenciado ao atravessar a próxima fronteira, de desconfiança e estranhamento dos moradores da região, dita como o "lado de lá da Farrapos". 


\section{Fronteira Farrapos}

A avenida Farrapos liga o centro da cidade até o Aeroporto Internacional de Porto Alegre, estendendo-se por 5,5 km. Como a maioria das avenidas, foi construída com o objetivo de facilitar e dar fluidez ao tráfego de veículos. Contudo, ao ligar pontos na perspectiva do automóvel e da escala macro da cidade, também rompeu diversas conexões anteriormente existentes na perspectiva do pedestre e na escala humana, cortando ao meio os bairros pelos quais se estende.

A posterior implantação de um corredor de ônibus também contribuiu para configurar o cenário que se observa hoje: uma avenida com 6 pistas, de tráfego intenso e de alta velocidade, e transposição pelos pedestres esbarra em barreiras físicas e dificuldades de acessibilidade ao longo de muitos pontos em sua extensão. Segregar fisicamente o território contribuiu para que as habitações e as atividades localizadas à leste e à oeste da avenida passassem a se desenvolver com suas próprias dinâmicas. Portanto, considerando tais características, a avenida Farrapos é identificada como uma barreira. Essa percepção de barreira também é detectada entre atores sociais presentes no território.

Na avenida Farrapos, encontra-se muita atividade comercial, alocada em edificações apenas comerciais ou em térreos de edifícios residenciais - característica muito própria dos edifícios Art Deco ali situados (Figueiró, 2007). Contudo, apesar disso, observa-se uma predominância de comércios que não atraem uma atividade pedestre, mas sim são vinculados à sua função como avenida de fluxo intenso de veículos. Dessa forma, ali existem, por exemplo, mecânicas, borracharias e postos de gasolina. Adiciona-se a esse cenário uma concentração de templos religiosos, muitos situados em grandes edificações térreas que parecem ser antigos depósitos, alguns em pequenos espaços térreos comerciais, sendo predominantes os templos pentecostais, os quais não apresentam ornamentos, mais típicos dos templos católicos. Tais estabelecimentos religiosos contrastam com as boates noturnas e as atividades de prostituição, sobretudo na porção mais próxima à Estação Rodoviária. Tais atividades perduram até hoje como um dos estigmas que marcam a percepção da avenida Farrapos no senso comum.

Nas ruas internas desse fragmento do bairro, entre a avenida Farrapos e rua Voluntários, encontram-se ruas pouco arborizadas salvo exceções, tais como a rua Paraíba. Nessa rua, concentra-se uma sequência de casas em fita, antigas moradias operárias preservadas. Nessa porção do bairro, encontra-se, também, um espaço público com área verde, a praça Dante Santoro, em formato triangular, aberta e equipada com quadra esportiva e área de lazer infantil, rodeada principalmente por pequenos estabelecimentos comerciais e pela avenida Farrapos.

As casas em fita contrastam com os grandes lotes também provenientes do período industrial (fábricas e depósitos), alguns ainda em atividade. Adiciona-se, a esses elementos, a presença de muitas edificações desocupadas que se tornaram ruínas, mantendo apenas a fachada ou estando em péssimo estado total de conservação. Nesses locais, é visível uma forte presença de pixos e grafites, intervenções que, em contraste com a fronteira da avenida Cristóvão, foram pintados em um contexto ilegal, o que acaba associando-os 
a uma imagem de abandono e descaso. Esses elementos até então mencionados podem ser visualizados na Figura 5.

Em uma das ruas cortadas pela avenida Farrapos também se encontra o local da nova sede do Museu de Arte Contemporânea do Rio Grande do Sul (MACRS). Trata-se de um imóvel público, do Patrimônio Estadual, com área de $2.890 \mathrm{~m}^{2}$ (Varela, 2019). Ainda em processo de instalação, a sede do museu nesse território expandirá a atuação do setor da economia criativa no bairro Floresta, transpondo à avenida Farrapos. O local da nova sede do MACRS situa-se ao lado de um albergue municipal, recentemente fechado pela prefeitura e que servia para acolhimento de moradores em situação de rua, mas que mudou de endereço após o estabelecimento de parcerias entre a prefeitura e organizações da sociedade civil.

Figura 5 - Elementos da paisagem que compõem a fronteira Farrapos e sua área interna no bairro Floresta
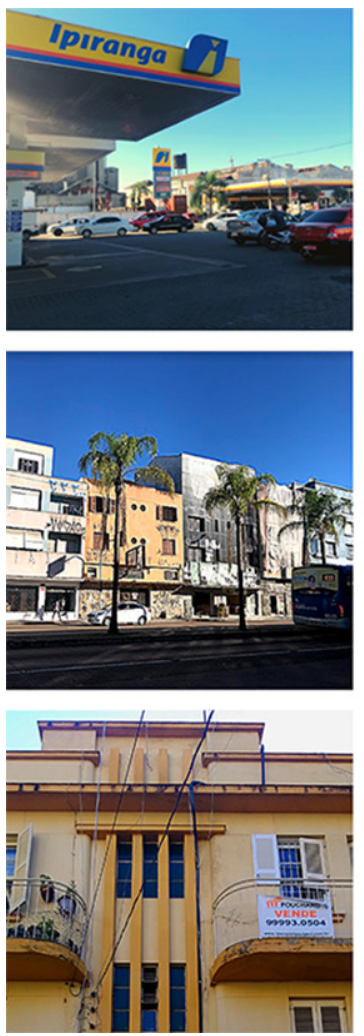
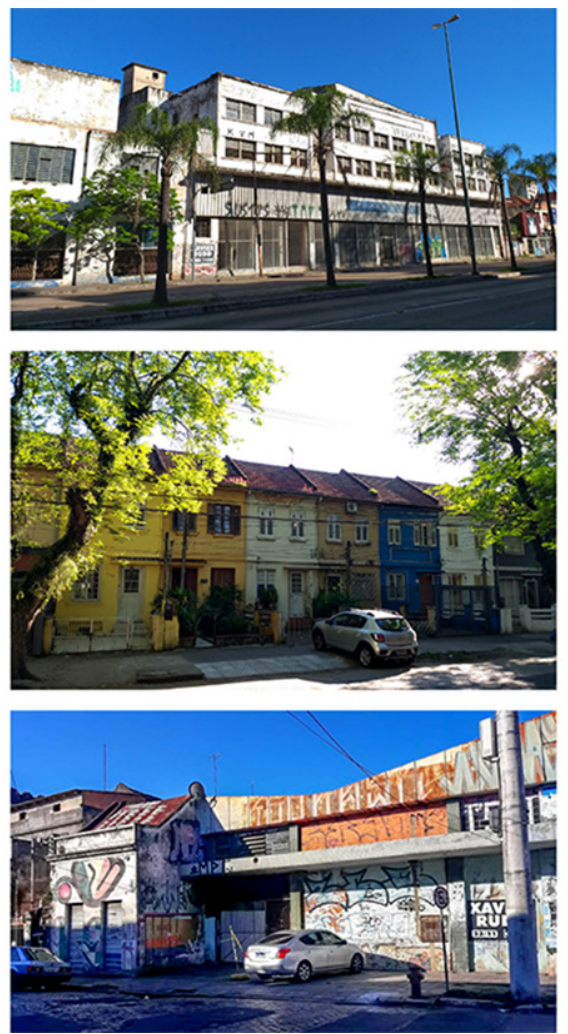
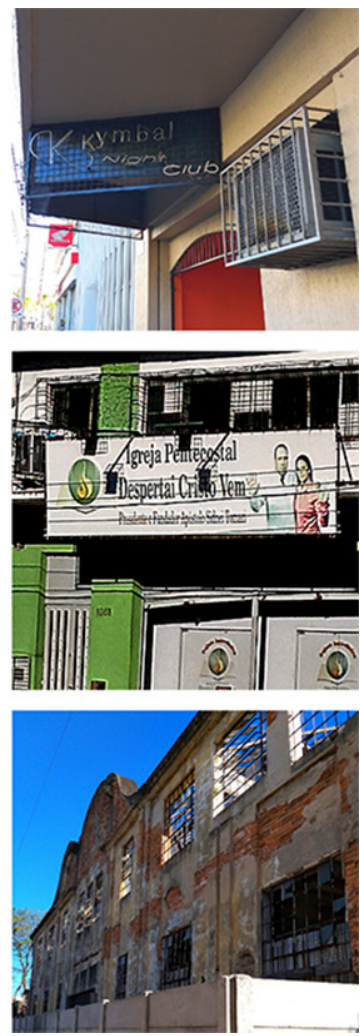

Fonte: trabalho de campo do GPSUIC, em 2019. 
Ainda, iniciativas como o Galpão Makers, por exemplo, usufruem das características das edificações ali presentes - a grande metragem dos galpões e a distância de usos residenciais - que permitem o desenvolvimento de atividades de produção de diversos tipos, tais como roupas, móveis, bicicletas, objetos de design, por vários empreendedores de iniciativas distintas, usufruindo de espaços em um grande galpão com infraestrutura compartilhada (Moraes, 2017). Além disso, bares, cervejarias e pubs, existentes em maior concentração no bairro vizinho, São Geraldo, também encontram vantagens nesse território, principalmente em relação à ausência de usos residenciais. Assim, pode-se citar, como exemplos, os bares Fuga e Cortex, recentemente inaugurados e situados no bairro Floresta.

Esses espaços, atividades e seus respectivos atores sociais presentes no território conformam uma territorialidade vinculada às suas atividades de trabalho, seja em função da coleta de resíduos e reciclagem, das boates noturnas, de hotéis, de depósitos, ou dos demais estabelecimentos de comércio popular encontrados no local. Junto a isso, os "vazios" identificados revelam uma especulação latente, possivelmente em função dos estigmas construídos sobre a área e da presença de populações em situação de vulnerabilidade, mas debruça seus interesses na proximidade geográfica com o centro da cidade e nas conexões metropolitanas e até mesmo internacionais. Ainda, observa-se a tímida transposição da avenida Farrapos por estabelecimentos vinculados à economia criativa (museu, escritórios de coworking, bares/pubs). Tal dinâmica ali observada se difere do que se encontra logo ao cruzar a terceira via que corta o bairro, a rua Voluntários da Pátria.

\section{Fronteira Voluntários da Pátria}

A rua Voluntários da Pátria caracteriza-se fortemente pela presença de pontos de compra de materiais recicláveis. Ao andar por essa rua, nota-se o fluxo de pessoas que coletam e fazem triagem desses materiais para a venda, puxando seus carrinhos, andando na margem da pista de veículos. Nesse território está também a Ksa Rosa, antiga ocupação que atua junto aos trabalhadores da reciclagem, promovendo atividades educativas. Adicionalmente, situam-se, nessa rua, pequenos comércios populares, borracharias e estacionamentos. $\mathrm{Na}$ região próxima à Estação Rodoviária, situam-se alguns hotéis, posto de gasolina, lancherias e grandes templos religiosos. Excetuando-se as edificações que abrigam tais atividades, poucas são as que possuem abertura para a rua Voluntários da Pátria, tornando-a ladeada por muros, paredes e grades. Entre as exceções, estão a sede da escola de samba Bambas da Orgia e a Secretaria de Segurança Pública do Estado. A paisagem desse território é ainda bastante desértica, carente de arborização e com calçadas estreitas e precárias em muitos trechos (Figura 6).

Apesar de os antigos investimentos para escoamento industrial terem diminuído, a rua Voluntários da Pátria permanece tendo importância estratégica por ser entrada da cidade. Atualmente, isso se evidencia no prolongamento da rua com nova pavimentação feita de material PVS, construída pelo pacote das obras da Copa do Mundo de 2014. 0 antigo Caminho Novo, dessa forma, entra nos projetos de embelezamento estratégico, pois é a via de prolongamento da Arena do Grêmio até o centro de Porto Alegre, passando por todos os bairros 
Figura 6 - Elementos da paisagem que compõem a fronteira Voluntários e sua área interna no bairro Floresta
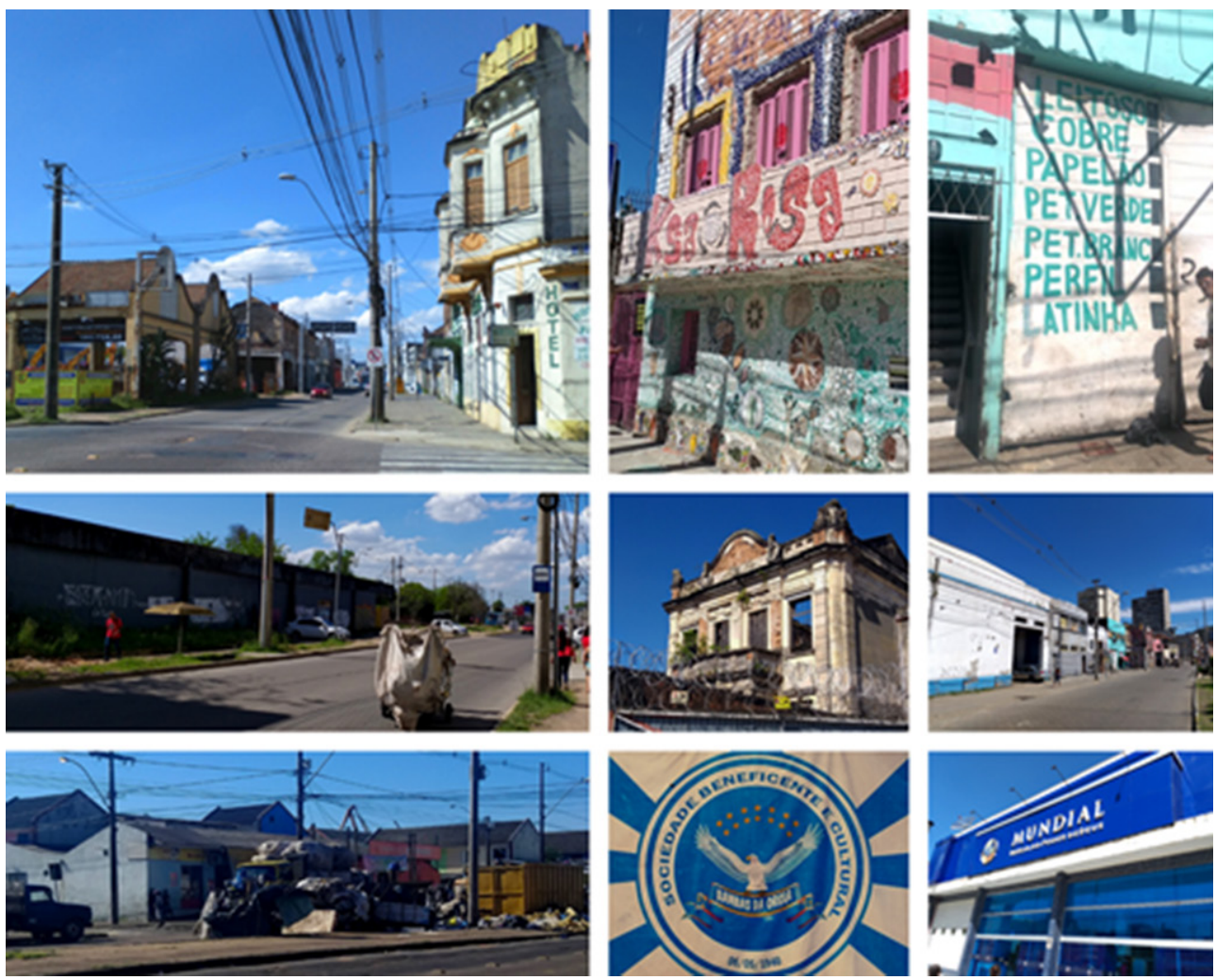

Fonte: trabalho de campo do GPSUIC, em 2019.

do 4 을 Distrito. Entretanto, esse novo elemento de investimento para melhoria da estrada se estabeleceu sem a refuncionalização do espaço destinado às pessoas, ao contrário, aprofundou um cenário de obras misturado com as ruínas, gerando embates dos atores inseridos naquele espaço com o poder público.

Na porção do bairro Floresta entre a rua Voluntários da Pátria e a avenida Castelo Branco, que correm paralelas, poucos são os usos residenciais, predominando grandes galpões utilizados como depósitos e garagens de empresas de Transportes Rodoviários. Nessa área também está localizada a vila Santa Terezinha, que, desde a década de 1980, era formada por habitações autoconstruídas e, posteriormente, veio a ser demarcada pela prefeitura como área de interesse social e receber obras de infraestrutura e novas unidades habitacionais - os sobrados, que hoje a compõem (Santos, 2018). Na vila, são revelados índices socioeconômicos destoantes do bairro: a renda per capita está em $\mathrm{R} \$ 385,91$, bem abaixo da média do Floresta; baixa escolaridade 
(10,89\%) e IDH de 0,593 (Pnud, 2014). Atualmente, paira sobre essa área um forte estigma associado à visível presença de "lixo" e à existência do tráfico de drogas, em virtude principalmente da retratação das ações policiais dos telejornais (Santos, 2018).

Dentro da vila Santa Terezinha, são desenvolvidas algumas iniciativas de trabalho social por outros atores locais do Floresta, dentre os quais pode-se citar as ações da Associação Vila Flores e da Paróquia Santa Teresinha. A Associação Vila Flores realiza atividades culturais, como o "de Vila a Vila", a construção de pista e aulas de skate, as oficinas diversas e a apresentação no evento Virada Sustentável - ações que colocaram principalmente os jovens que vivem nesse espaço em maior contato com outros espaços culturais locais.

A Paróquia Santa Terezinha (que inclusive compartilha o nome com a Vila), por sua vez, desenvolve um trabalho de assistência social para os moradores a partir de doações de itens, como cestas básicas, roupas, brinquedos, móveis e eletrodomésticos (ibid.). Seu atendimento ocorre por meio socioeducativo através da escola marista de educação infantil Menino Jesus, construída no loteamento para atendimento de crianças na faixa etária dos 4 meses aos 6 anos em projetos pedagógicos, atividades lúdicas e recreativas.

Os fluxos que se movimentam e cruzam a rua Voluntários se limitam aos catadores de materiais, que circulam pela cidade para captar materiais recicláveis, e algumas aproximações por via do assistencialismo, ainda que sempre cortados pela velocidade dos carros e caminhões que determinam um espaço de pouco acessibilidade. Os elementos compostos nesse cenário urbano e essa organização doméstica e de trabalho dos atores sociais se misturam na construção dessa territorialidade deslocada por muros e cercas na fronteira, que ressaltam ainda mais a estigmatização criada, ainda que tenham suas divisões internas de grupos sociais distintos. Entretanto, até o final deste artigo, não foram realizadas caminhadas na vila Santa Terezinha, de forma que isso limitou a análise da área interna da Vila aos dados coletados em fontes secundárias.

\section{Considerações finais}

Os processos históricos que se sucederam sobre o 4 음 Distrito gravaram nele a sua paisagem. Hoje, esses processos são apropriados por distintas narrativas produzidas por atores sociais que guardam alguma relação com o território. Além disso, mais do que narrativas, os agentes seguem produzindo, alterando, reconstruindo continuamente a paisagem, em um processo ininterrupto. Assim, analisar o passado faz sentido especialmente quando se percebe que o amanhã é definido pelo hoje e, sobretudo, quando se enxergam potenciais transformações prestes a acontecer, como é o caso atual do bairro Floresta.

Nesse sentido, conforme Harvey (1982), depreende-se que os conflitos presentes no ambiente construído explicitam o conflito inerente das sociedades capitalistas. Com isso, reconhece-se que algumas mudanças acabam sendo enquadradas por determinados atores sociais em um processo de criação de um imaginário urbano atraente, direcionado à atração de investimentos, e não necessariamente ao atendimento de necessidades locais (Harvey, 1996). Por exemplo, pode-se citar o empenho 
em obras de infraestrutura para a Copa por parte do poder público local, observado em partes do bairro Floresta.

Além disso, os elementos estruturais que compõem a paisagem urbana constituem a territorialidade dos atores inseridos de diferentes períodos históricos, conforme os processos de mudança aos novos paradigmas socioeconômicos. Os locais, portanto, sugerem uma interrelação entre os sujeitos e traduzem a dimensão política do espaço geográfico, por conterem, em seu interior, desejos e intencionalidades expressas por meio de diferentes formas de poder (Araujo e Haesbaert, 2007). Algumas formas de reorganização desse território, portanto, levaram a novos significados com o processo dialético de rugosidade dessa paisagem industrial (Santos, 1985) e do esvaziamento dela. São reconfigurações, tais como o processo de crescimento do setor terciário, a economia criativa, a concentração de áreas populares e a ocupação pela criação de zonas especiais de habitação na área.

A heterogeneidade de elementos que foram sendo materializados na área desde o seu processo de urbanização inicial, sobretudo ao longo das décadas de forte industrialização do 40 Distrito, hoje encontram novos usos. Para retomar alguns exemplos, sobrados foram transformados em boates, galpões foram transformados em templos religiosos e em coworkings. Junto a estes, encontram-se os elementos não renovados ou não reapropriados, tais como as ruínas e os imóveis desocupados. Por sua vez, esses elementos evidenciam, na verdade, uma disputa, justamente por estarem em um território em que ocupações que lutam pelo direito coletivo à cidade convivem com novos condomínios verticais, os quais reforçam um modo de vida baseado na individualidade.
Como observado, os empreendedores da indústria criativa concentram-se, sobretudo, nas proximidades da avenida Cristóvão Colombo, aproveitando a infraestrutura regular, e reforçam as diferenças dos perfis socioeconômicos internos do bairro. Os empreendimentos desse segmento instalam-se a partir de espaços refuncionalizados, de antigos sobrados e casas preservadas, próximos do centro da cidade e de uma alta concentração de serviços urbanos. A presença de edificações pequenas que tendem a atrair negócios pequenos, que, por sua vez, conectam-se em redes, acaba por ampliar seu poder de atuação enquanto atores sociais. Apesar de estarem majoritariamente concentrados próximos à avenida Cristóvão Colombo e à rua São Carlos, já se observa a existência de empreendimentos criativos na área entre a avenida Farrapos e a rua Voluntários da Pátria.

Também é importante chamar a atenção para os grandes projetos de requalificação urbana para remodelação do 4음 Distrito e para a atração de investimentos, que podem levar à expulsão de moradores desse cenário urbano, especialmente os que estão concentrados entre a avenida Farrapos e a rua Voluntários da Pátria. São as chamadas "revitalizações" que, pelo termo, invisibilizam as vivências e as conexões dos diferentes atores que resistem a essas imposições. Tendo em vista o contexto apresentado neste trabalho, a segregação territorial e a alteração nos padrões arquitetônicos e urbanos deixados pela época industrial, para a inserção aos novos paradigmas de investimentos financeiros econômicos privados, podem provocar o deslocamento dos moradores de menor poder aquisitivo, como os moradores em situação de rua, as trabalhadoras do sexo, os papeleiros e os pequenos comerciantes populares. 
A heterogeneidade é a mais notável característica desse território. A diversidade de espaços e de configurações possibilita a existência de uma ampla gama de atividades e de convivência entre negócios, sobretudo, entre públicos distintos. Contudo, a existência de três fronteiras identificadas dentro do bairro, que o segregam em distintas territorialidades, bem como a existência de poucos espaços públicos para a promoção da sociabilidade, são fatores que não contribuem para a integração e resolução de conflitos entre os diferentes atores sociais. Nesse sentido, futuras investigações podem contribuir para aprofundar o conhecimento sobre outros atores sociais que representam a heterogeneidade de pertencer ao bairro Floresta, explorando suas redes de conexões, suas diferentes formas de uso e suas narrativas sobre o bairro Floresta e o 4음istrito.

\section{[I] https://orcid.org/0000-0001-5202-0765}

Universidade Federal do Rio Grande do Sul, Instituto de Filosofia e Ciências Humanas, Programa de Pós-Graduação em Sociologia. Porto Alegre, RS/Brasil.

luizhapollo@gmail.com

\section{[II] https://orcid.org/0000-0001-7733-2079}

Universidade Federal do Rio Grande do Sul, Faculdade de Arquitetura, Programa de Pós-Graduação em Planejamento Urbano e Regional. Porto Alegre, RS/Brasil.

vitoriagonzatti@live.com

\section{Nota}

(1) A região entre a avenida Cristóvão Colombo e a rua Marquês do Pombal pertencia ao bairro Floresta até 2016, quando houve uma alteração na lei de bairros de Porto Alegre. As modificações nos limites do bairro Floresta incluíram a demarcação dessa região como parte ao bairro Moinhos de Vento.

\section{Referências}

ARANTES, O. B. F.; MARICATO, E.; VAINER, C. (orgs.) (2000). A cidade do pensamento único: desmanchando consensos. Petrópolis, Vozes.

ARAUJO, F. G. B de; HAESBAERT, R. (orgs.) (2007). Identidades e territórios: questões e olhares contemporâneos. Rio de Janeiro, Acess. 
BOURDIEU, P. (1983). “Esboço de uma teoria da prática”. In: ORTIZ, R. (org.) Pierre Bourdieu: Sociologia. São Paulo, Ática.

CONSTANTINO, N. S. (1998). Espaço urbano e imigrantes: Porto Alegre na virada do século. Estudos Ibero-Americanos. Porto Alegre, v. XXIV, n. 1, pp. 149-164.

CORRÊA, R. L. (2018)." Sobre Agentes Sociais, escala e produção do espaço: um texto para discussão". In: CARLOS, A. F. A.; SOUZA, M. L.; SPOSITO, M. E. B. (orgs.). A produção do espaço urbano: agentes e processos, escalas e desafios. São Paulo, Contexto.

COSTA, A. B. (1989). Algumas características da industrialização gaúcha. Ensaios FEE. Porto Alegre, v. 10, n. 1, pp. 24-46.

CULLEN, G. (2015). Paisagem urbana. Lisboa, Edições 70.

CUNHA, J. L. (2006). “Imigração e colonização alemã”. In: BOEIRA, N.; GOLIN, T. (coords.). História Geral do Rio Grande do Sul. Passo Fundo, Méritos.

DE CERTEAU, M. (1998). A invenção do cotidiano. Petrópolis, Vozes.

FERNANDES, A. C. (2014). Cemitérios industriais: contribuição para a análise espacial da metrópole de Porto Alegre/RS Brasil. Tese de doutorado. Porto Alegre, Universidade Federal do Rio Grande do Sul.

FIGUeIRÓ, A. F. (2007). Art Deco no Sul do Brasil: O caso da Avenida Farrapos, Porto Alegre/RS. Dissertação de mestrado. Brasília, Universidade de Brasília.

FORTES, A. (2001). Nós do Quarto Distrito: a classe trabalhadora porto-alegrense e a era Vargas. Tese de doutorado. Campinas, Universidade Estadual de Campinas.

FRANCO, S. C. (1982). Porto Alegre: guia histórico. Porto Alegre, Ed. UFRGS.

HAESBAERT, R. H. (2004). O mito da desterritorialização: "do fim dos territórios" à multiterritorialidade. Rio de Janeiro, Bertrand Brasil.

HARVEY, D. (1982). O trabalho, o capital e o conflito de classes em torno do ambiente construído nas sociedades capitalistas avançadas. Espaço e debates, v. 6, pp. 6-35.

(1996). Do gerenciamento ao empresariamento: a transformação da administração urbana no capitalismo tardio. Espaço \& debates, n. 39, pp. 48-64.

(2014). Cidades rebeldes: do direito à cidade à revolução urbana. São Paulo, Martins Fontes.

JACOBS, J. (2011). Morte e vida de grandes cidades. São Paulo, Martins Fontes.

LEFEBVRE, H. (2001). O direito à cidade. São Paulo, Centauro.

MATTAR, L. N. (2010). A modernidade em Porto Alegre: arquitetura e espaços urbanos plurifuncionais em área do 4ํ distrito. Tese de Doutorado. Porto Alegre, Pontifícia Universidade Católica do Rio Grande do Sul.

MIRANDA, A. E. (2003). Localização dos principais edifícios de fábricas em Porto Alegre. Dissertação de mestrado. Joinville, Universidade Federal do Rio Grande do Sul.

MORAES, B. (2017). Revitalização do 4o Distrito: Galpão Makers reúne 24 empresas que produzem em espaço coletivo. GAÚCHA ZH. Disponível em: <https://gauchazh.clicrbs.com.br/portoalegre/noticia/2017/11/revitalizacao-do-4o-distrito-galpao-makers-reune-24-empresas-queproduzem-em-espaco-coletivo-cj9uk9h6701hl01ms95e4nenq.html. Acesso em: 5 jun 2020. 
PACHECO, R. A. (2005). A modernidade envolve o campo político: representações e práticas do processo eleitoral na Porto Alegre da década de 1920. Revista Brasileira de História. São Paulo, v. 25, n. 50, pp. 97-130.

PESAVENTO, S. J. (1985). História da Indústria Sul-Rio-Grandense. Guaíba, Riocell.

PETERSEN, S. R. F. (2001). Que a união operária seja nossa pátria - História das lutas dos operários gaúchos para construir suas organizações. Santa Maria/Porto Alegre, Editora da UFSM/ Editora da UFRGS.

PNUD (2014). Ocupações das Unidades de Desenvolvimento Humano (UDH) da Orla do Guaíba (20002010). Disponível em: <http://www.atlasbrasil.org.br/2013/pt/perfil_udh/22221>. Acesso em: abr 2020.

PORTO ALEGRE (1959). Lei n. 2.046, 30 de dezembro de 1959. Institui o Plano Diretor e fixa normas para sua execução. Porto Alegre, RS.

(1979). Lei complementar n. 43, 21 de julho de 1979. Dispõe sobre o desenvolvimento urbano no Município de Porto Alegre, institui o Primeiro Plano-Diretor de Desenvolvimento Urbano, e dá outras providências. Porto Alegre, RS.

ROCHE, J. (1969). A colonização alemã e o Rio Grande do Sul. Porto Alegre, Globo.

SANTOS, E. L. S. (2018). Loteamento Santa Terezinha em Porto Alegre/RS: entre a aparente permanência e a tênue mudança. Dissertação de mestrado. Porto Alegre, Universidade Federal do Rio Grande do Sul.

SANTOS, M. (1982). Espaço e sociedade: Ensaios. Petrópolis, Vozes.

(1985). Espaço e método. São Paulo, Hucitec.

SILVA, L. H. A. (2019). Reestruturação urbana do bairro Floresta: uma vitrine para o projeto de cidade criativa de Porto Alegre. 2019. Dissertação de mestrado. Porto Alegre, Universidade Federal do Rio Grande do Sul.

SPALDING, W. (1967). Pequena história de Porto Alegre. Porto Alegre, Sulina.

TITTON, C. P. (2012). Reestruturação produtiva e reestruturação urbana: o caso do 4o distrito de Porto Alegre. Dissertação de mestrado. São Paulo, Universidade Presbiteriana Mackenzie.

VARELA, R. (2019). Museu de Arte Contemporânea terá sede própria, anuncia secretária da Cultura. Disponível em: https://estado.rs.gov.br/museu-de-arte-contemporanea-do-rs-tera-sedepropria-anuncia-secretaria-da-cultura. Acesso em: 31 maio 2020.

ZUKIN, S. (1989). Loft living: cultural and capital in urban change. New Brunswick, Rutgers University Press. 